\title{
Vliv pobytového programu o Jizerských horách na proenvironmentální postoje a hodnoty
}

\author{
Jan Činčera \\ Envigogika 2011/VI/3- Recenzované články/ Reviewed Papers \\ Publikováno/Published 31. 12. 2011 \\ DOI: http://dx.doi.org/10.14712/18023061.64
}

\begin{abstract}
Abstrakt:
Článek prezentuje evaluaci programu environmentální výchovy nabízeného Střediskem ekologické výchovy Jizerka. První část popisuje cíle programu a předcházející formativní evaluaci. $\vee$ té program prokázal vliv na znalosti žákủ o Jizerských horách a porozumění vybraným ekologickým konceptům. Protože výzkum naznačil, že žáci mají problémy formulovat vlastní názor na problematiku, byl v roce 2011 realizován výzkum vyhodnocující vliv programu na formování proenvironmentálních postojů. Výzkum proběhl kvaziexperimentální formou pretest/posttest na vzorku 53 žáků. Pro sběr dat byl využit standardizovaný dotazník TEQ, používaný pro evaluaci programů výchovy o Zemi. Výzkum neprokázal vliv programu na žádný ze sledovaných postojů. $V$ poslední části jsou diskutovány možné důvody a návrhy na modifikaci programu.
\end{abstract}

\section{Klíčová slova:}

Evaluace, proenvironmentální postoje, ochrana přírody, využívání přírody

\begin{abstract}
:
This article presents an evaluation of a program provided by The Center for Environmental Education Jizerka. The first part describes the program's goals and results of a precedent evaluation. In that, the program appeared to influence pupils' knowledge of Jizera mountains and awareness of selected ecological concepts. Because the research suggested that pupils failed in formulating their own opinion on a topic, following research investigating the impact on forming proenvironmental attitudes was realized in 2011. The research was based on quasi-experimental pre/posttest design on the sample of 53 pupils. A standardized questionnaire TEQ used for evaluation of Earth education programs was applied. The research did not prove an impact of the program on any of investigated attitudes. In the last part, possible explanations and suggestions for program modifications are discussed.
\end{abstract}

\section{Key words:}

Evaluation, proenvironmental attitudes, conservation, nature utilization 


\section{Úvod}

Evaluace je základním předpokladem efektivity každého programu. Pomocí evaluačního výzkumu můžeme posoudit, zda a do jaké míry program naplňuje své očekávané výstupy, jak je program účastníky prožíván a interpretován a jaké jsou jeho př́ípadné další dopady (Rossi, Lipsey \& Freeman, 2004). Evaluace mohou být zaměřeny poměrně úzce a vyhodnocovat míru dosažení očekávaných výstupů programu, zpravidla získaných znalostí a dovedností. Lze ale předpokládat, že kromě definovaných očekávaných výstupů může program rozehrávat řadu dalších změn v postojích, hodnotách či chování účastníků. Takové změny mohou být bud' explicitně předpokládány teorií programu a označovány jako střednědobé či dlouhodobé cíle programu, nebo může jít o nepředpokládané, více či méně žádoucí vedlejší efekty, označované jako "implicitní teorie programu" (Rossi, Lipsey \& Freeman, 2004). Právě tyto širší efekty mohou být důležité pro posouzení smyslu programu v kontextu cílů environmentální výchovy.

Program Vyšetřování jizerskohorské katastrofy pro 4. - 6. tř́́du (dále jen Vyšetřování) byl evaluován po prvním roce svého fungování na přelomu let 2010/11. Provedený výzkum prokázal, že program naplňuje většinu svých očekávaných výstupů a pozitivně ovlivňuje znalosti dětí ve sledovaných oblastech. Má ale program vliv také na proenvironmentální postoje a hodnoty dětí? Program sice explicitně nezahrnuje mezi své cíle vliv na postoje žáků $k$ př́rodě, předpokládá ale, že bude formovat jejich postoje k ohleduplnému chování $v$ prrírodě (Činčera, Kavan \& Šedlbauer, 2010).Lze proto předpokládat, že proenvironmentální postoje a hodnoty jsou součástí implicitní teorie programu a že by efekt programu na související proměnné byl realizátory považován za žádoucí.

Prezentovaný výzkum se proto zaměřuje na vyhodnocení vlivu programu na vybrané proenvironmentální hodnoty a postoje. $\mathrm{V}$ první části text shrnuje základní informace o teorii programu a jeho dosavadní realizaci. Ve druhé shrnuje poznatky o fungování programu vycházející z evaluačního výzkumu provedeného na přelomu let 2010/11. Ve třetí části prezentuje metodologii a výsledky nového evaluačního výzkumu zaměřeného na postoje a hodnoty. $V$ poslední části jsou diskutovány výsledky a navrhovány změny v programu.

\section{Popis programu}

Program Vyšetřování jizerskohorské katastrofy vznikl v rámci projektu „Člověk a krajina Jizerských hor" (reg. č. CZ.1.07/1.1.09/02.0061), který byl podpořen z Operačního programu Vzdělávání pro konkurenceschopnost. $\mathrm{Na}$ jeho vytváření spolupracovala Společnost pro Jizerské hory, o.p.s. a Technická univerzita v Liberci. Cílem programu je formovat vztah žáků $k$ přírodě Jizerských hor a vést je $k$ pochopení příčin současného stavu jizerskohorských lesů (Činčera, Kavan \& Šedlbauer, 2010). Teorie programu je vyjádřena pomocí logického modelu: 
Obr. č. 1. Logický model programu Vyšetřování jizerskohorské katastrofy pro 4. - 6. třídu

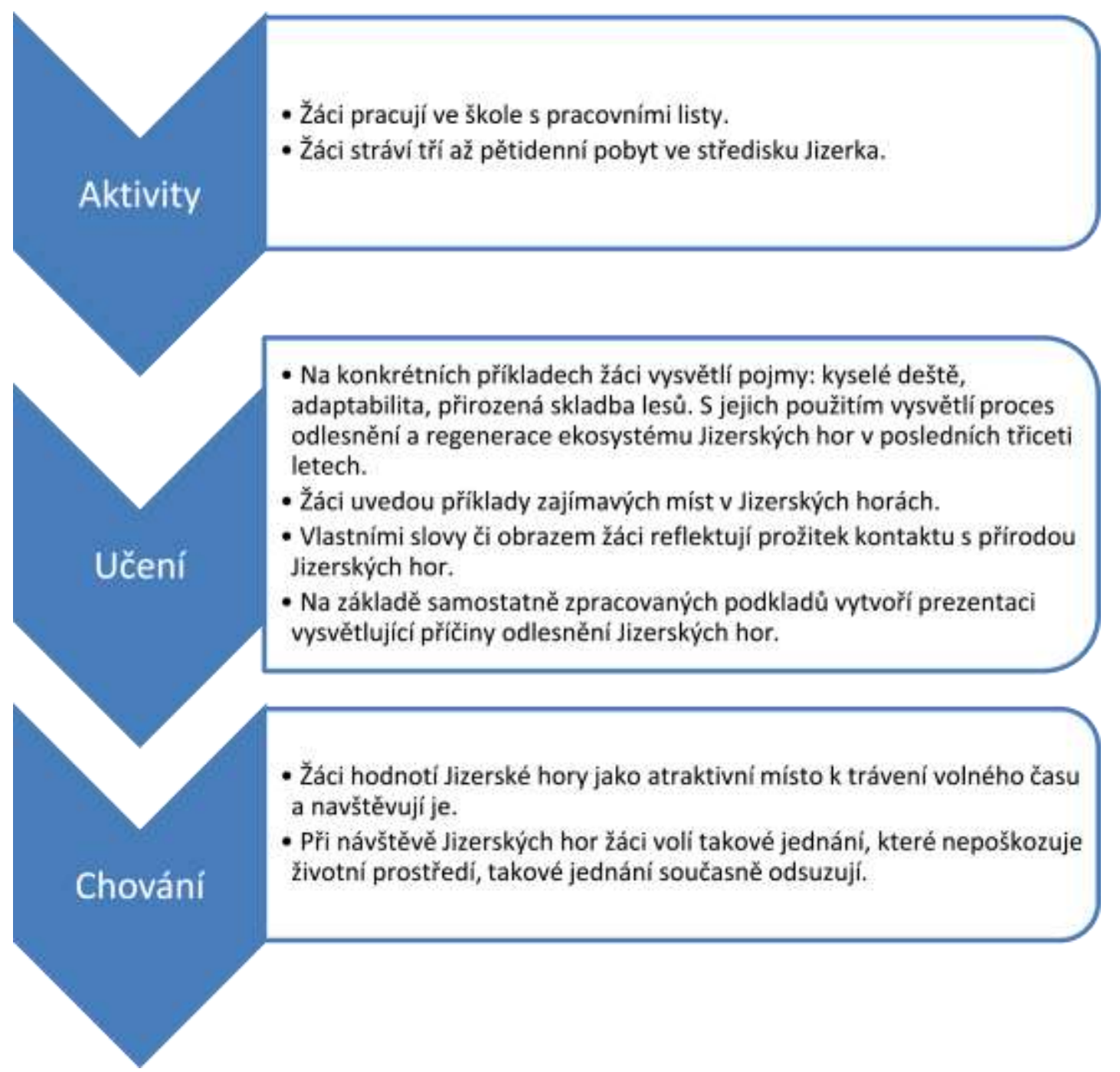

Činčera, Kavan \& Šedlbauer, 2010.

Program začíná ve škole a jeho první část je řizena pomocí pracovních listů. Těmi provádí žáky fiktivní postava americké studentky s českými kořeny Susan a pracovníka Střediska ekologické výchovy Jizerka Dejva. Susan se zajímá o své kořeny. Pomocí Facebooku se obrací na Dejva a ptá se ho na současný stav Jizerských hor, ve kterých vyrůstala její babička. Je šokovaná tím, co se v Jizerských horách $v$ posledních desetiletích děje, a zajímají ji príčiny.

Program v první části obsahuje aktivity, ve kterých žáci sdílejí své zkušenosti a zážitky z Jizerských hor. Dejv pomocí textů, prezentace i úkolů provází Susan i žáky historií Jizerských hor a postupně ukazuje prríčiny jejich odlesňování v 70. a 80. letech 20. století. Z dodaných informací žáci navrhnou seznam možných př́čin rozsáhlého poškození lesů. Stávají se "detektivy": každý tým si vybere jednu možnou příčinu katastrofy („stopu") a najde si k ní další informace, které pak bude prezentovat.

Třída pak odjiždí na středisko do obce Jizerka, kde se účastní tř́ či pětidenní verze programu. V jeho průběhu žáci hledají v terénu podklady pro vyhodnocení své "stopy". 
Kromě samotného průzkumu $v$ terénu žáci dostanou další podklady $v$ podobě přednášky místního ochránce př́rody a interpretativních výletů do okolí. $V$ průběhu programu je dále posilována spolupráce mezi dětmi formou kooperativních her.

V závěrečné části týmy prezentují výsledky svého pátrání: co se o své "stopě" dozvěděly a do jaké míry zkoumaná přícina ovlivnila stav lesů v Jizerských horách.

"Vyšetřování jizerskohorské katastrofy" je jedním ze tří pobytových programů realizovaných v rámci SEV Jizerka. Druhým z programů je "Vyšetřování jizerskohorské katastrofy pro 7. - 9. ročník", které se zaměřuje na rozvoj výzkumných dovedností. Třetím je "Člověk a krajina Jizerských hor - strategie budoucího využívání", ve kterém se žáci středních škol učí analyzovat územní konflikty.

\section{Evaluace očekávaných výstupů programu}

Program Vyšetřování byl zahájen na počátku sezóny (duben) 2010. V průběhu celé sezóny do konce ř́ijna 2010 probíhal současně sběr dat pro jeho evaluaci. Cílem šetření bylo zjistit, do jaké míry program naplňuje své očekávané výstupy a jak jsou učitelé s programem spokojeni. Výzkum proběhl $v$ rámci diplomové práce na Technické univerzitě v Liberci (Vlachová \& Činčera, 2011). V průběhu sezóny se programu zúčastnilo šest tř́́d s celkem 122 žáky, data se podařilo získat od 103 respondentů (84\%) a od všech doprovázejících učitelů. Pro zodpovězení evaluačních otázek byly využity metody monitoringu výstupů, porovnávající výsledky ve sledovaných kategoriích s předem stanovenými indikátory; kvaziexperiment, porovnávající výsledky žákovských testů před a po ukončení programu; rozhovory s učiteli a nestrukturované pozorování.

V rámci testu žáci odpovídali na otázky týkající se znalosti Jizerských hor a porozumění vybraným ekologickým pojmům (monokultura, kyselý déšt', přirozená skladba lesů). Výzkum dále pomocí hodnotící tabulky s předem definovanými kategoriemi (např. formulace příčin, vysvětlení, organizace prezentace, vyjádření vlastního názoru) hodnotil kvalitu prezentací výsledků vlastního výzkumu.

Výzkum potvrdil pozitivní dopad programu na většinu sledovaných proměnných. Žáci prokázali statisticky významné zvýšení skóre ve znalostech ekologických pojmů i znalostech lokalit v Jizerských horách. Výzkum současně ukázal, že vstupní znalosti žáků jsou ve sledovaných oblastech poměrně nízké a že přes naměřený efekt výsledky nedosahují hladiny, kterou realizátor programu považoval za žádoucí.

Výzkum dále ukázal, že žáci zpravidla umějí získávat i prezentovat nalezené informace, reflektovat svůj prožitek z pobytu, mají ale problémy s vyjadřováním svých postojů ke zkoumané problematice. Žáci zpracují informace a prezentují je jako "referát", nikoliv jako problém, ke kterému by měli hledat řešení a formulovat svoje stanovisko. Podle názoru dotazovaných učitelů je vyjadřování vlastních názorů k environmentálnímu problému pro žáky na prvním stupni přiliš náročné. Je ale také možné, že program žáky $\mathrm{k}$ formulaci postojů málo vede.

Učitelé program hodnotili převážně pozitivně. Současně ale upozorňovali na nedostatek času, kvůli kterému museli vynechávat některé aktivity ze školní části programu, prípadně nedali dětem dostatek prostoru na samostatné vyhledání informací a zpracování vstupní prezentace před odjezdem na pobytovou část.

\section{Metodika evaluace vlivu programu na postoje a hodnoty dětí}

Druhý ročník Vyšetřování probíhal $v$ období duben-září 2011. Součástí byl opět evaluační výzkum, který probíhal $v$ průběhu celé sezóny. Explicitní teorie programu předpokládá vliv programu na postoje dětí k ohleduplnému chování k př́rodě Jizerských hor a na to, že se v souladu s tímto postojem budou samy chovat. Odpovědné chování je 
výsledkem souhry řady faktorů, mezi kterými hrají roli i proenvironmentální postoje a hodnoty. O vlivu postojů a hodnot na proenvironmentální chování neexistuje dosud shoda. Podle Sterna et al. (1999) jsou východiskem pro další rozhodování biocentrické hodnoty zastávané jedincem. Obdobně Dunlap a van Liere (1978) předpokládají vztah mezi souhrnem obecných postojů k životnímu prostředí, označovaném jako Nové environmentální paradigma (NEP), a chováním. Jiní autoři (Hungerford a Volk, 1990) považují efekt obecných proenvironmentálních postojů spíše za slabší a naopak zdưrazňují význam postojů specifických k určitému chování. V každém případě lze předpokládat, že je-li ambicí programu dlouhodobě ovlivňovat chování dětí, neměl by se vlivu na afektivní složku vyhýbat.

Vliv programu Vyšetřování na obecné proenvironmentální postoje je možné chápat jako součást implicitní teorie programu. Cílem evaluace bylo zjistit, zda program ovlivňuje postoje dětí k př́rodě a ochraně životního prostředí.

Známým nástrojem na měření obecných proenvironmentálních postojů je již zmíněný NEP (Dunlap \& van Liere, 1978). Nástroj byl založen na předpokladu, že je možné postoje k životnímu prostředí měřit pomocí jediné hlavní dimenze, totiž míry souhlasu s dominantním sociálním paradigmatem, respektive novým environmentálním paradigmatem. Nástroj využívá Likertovy škály pro vyjádření míry souhlasu s jednotlivými tvrzeními. V revidované podobě (Dunlap, van Liere, Mertig \& Jones, 2000; LaTrobe \& Acott, 2002) nástroj pracuje s pěti podškálami, odrážejícími různé aspekty nového environmentálního paradigmatu: reálnost mezí růstu, antiantropocentrismus, křehkost přírodní rovnováhy, odmítnutí výjimečnosti člověka a možnost ekologické krize. NEP byl v rưzných variantách využit i v českém prostředí (Soukup, 2001; Činčera \& Štěpánek, 2007; Bezouška \& Činčera, 2007; Bílek \& Schmutzerová, 2010).

Přestože výhodou NEP je jeho jednoduchost a rozšírení, nástroj může být chápán i jako př́liš zjednodušující. Bogner a Wiseman (in Johnson \& Manoli, 2008) proto vytvořili alternativní nástroj Model ekologických hodnot (MEV, v původní verzi ENV), který rozlišuje dvě základní dimenze vnímání životního prostředí: ochranu a využívání přírody. Faktor Ochrana vyjadřuje ochotu respondenta chovat se šetrně k životnímu prostředí, podporovat ochranu životního prostředí a mít radost z pobytu v přírodě. Faktor Využívání vyjadřuje souhlas s úpravami životního prostředí tak, aby lépe vyhovovalo lidským potřebám a s přesvědčením o právu člověka ovládat přírodu.

Nástroj se skládá ze série tvrzení, kterým se respondenti vyjadřují na Likertově škále (souhlasím-spíše souhlasím-nevím-spíše nesouhlasím-nesouhlasím). Výsledkem pak je zařazení respondenta do některého ze čtyř kvadrantů vyjadřujícího míru zájmu či nezájmu s ochranou přírody a jejím využíváním.

\author{
Ochrana (+) Zájem \\ Využívání (+) Nezájem \\ Využívání (+) Zájem \\ Ochrana (-) Nezájem
}




\section{Obr. č. 2. Model ekologických hodnot}

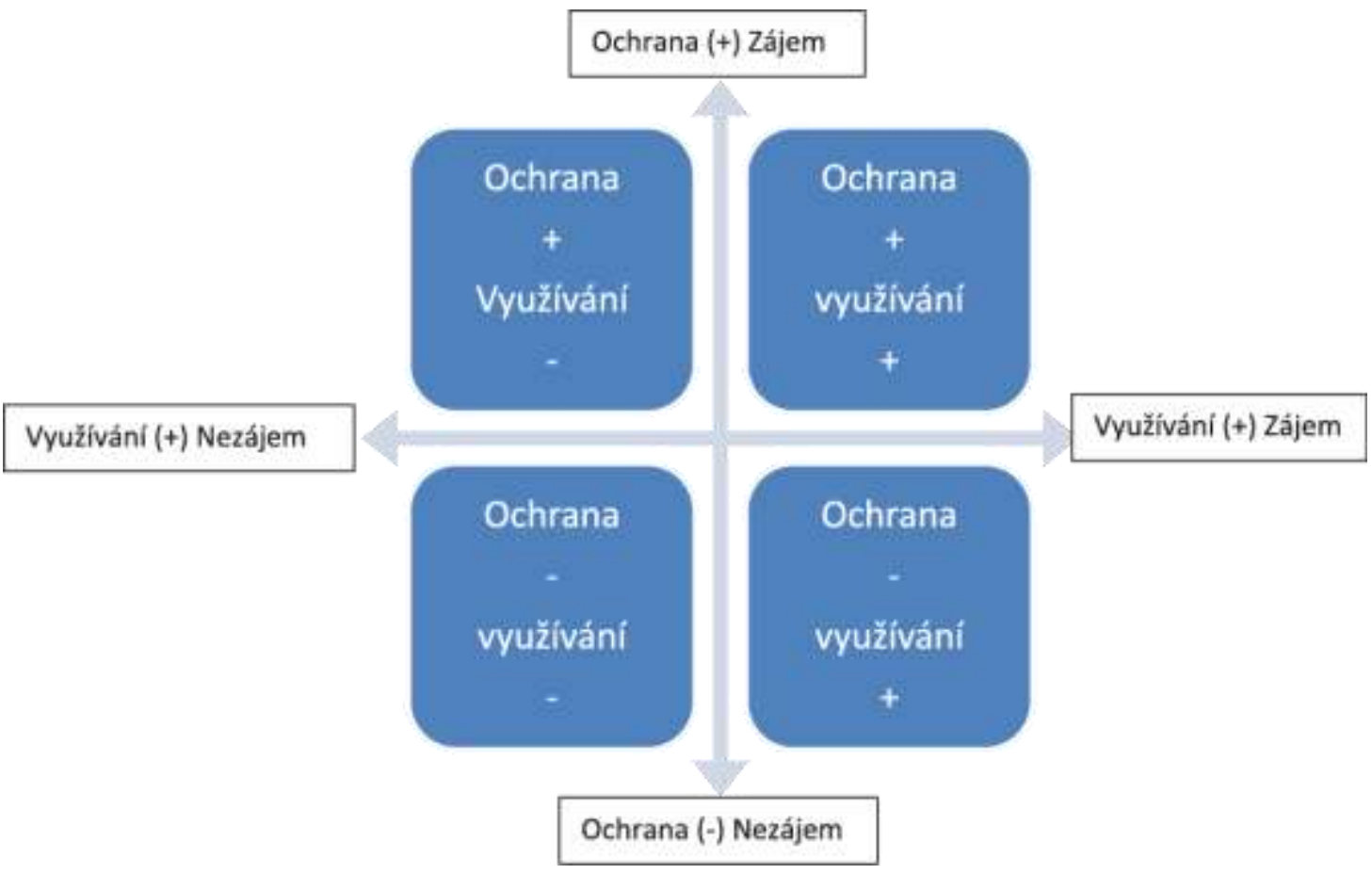

Johnson \& Manoli, 2008)

„Model ekologických hodnot" se pak stal východiskem pro tvorbu Dotazníku o životním prostředí (The Environment Questionnaire, TEQ, v. príloha 1), využívaném pro hodnocení vlivu programů výchovy o Zemi „Sunship Earth" (Matre, 1979) a „Earthkeepers" (Matre \& Johnson, 1998) na vnímání životního prostředí (Johnson \& Manoli, 2008; Johnson \& Manoli, 2008). "Sunship Earth" je pětidenní pobytový program, jehož jedním z hlavních cílů je rozvíjení vztahu k př́rodě. "Earthkeepers" má stejné cíle. Skládá se z pobytové části dlouhé dva a pưl dne a navazující práce ve škole.

TEQ se skládá ze dvou hlavních částí. První tvoří šestnáct položek z "Modelu ekologických hodnot". Ty jsou rozděleny do pěti primárních a dvou sekundárních (hlavních) faktorů:

Ochrana

- Odhodlání k podpoře

- Péče o zdroje

- Radost z prírody

Využívání

- Měnění přírody

- Dominance

Druhou částí je upravená škála NEP (Manoli, Johnson \& Dunlap, 2007). V rámci TEQ nejsou jednotlivé faktory NEP dále rozlišovány. 
Jednotlivé položky jsou v dotazníku zamíchány tak, aby na sebe nenavazovaly položky vztahující se ke stejnému faktoru. Respondenti se vyjadřují ke každé z nich na pětibodové Likertově škále. Odpovědi jsou dále bodovány tak, že za každé "souhlasím" získal respondent pět bodů, "spíše souhlasím" čtyři body, atd.

Johnson a Manoli (2008 a 2008) vyhodnocovali vliv programu na každý z primárních i sekundárních faktorů. Pro evaluaci "Sunship Earth" pracovali s experimentální skupinou o velikosti 482 respondentů a kontrolní skupinou čítající 127 respondentů. Pro analýzu byly vypočítány průměrné bodové zisky pro každou položku. Následně pak byla vyhodnocena statistická významnost pomocí párového, resp. nepárového t-testu. Evaluace naměřila statisticky významný vliv programu na většinu měřených faktorů.

Pro evaluaci Vyšetřování byl použit TEQ v původním českém překladu. Ve srovnání s výzkumem Johnsona a Manoli (2008 a 2008) byl ale vzorek podstatně menší, a bylo proto nutné zvolit jiný postup pro analýzu dat.

V průběhu sezóny 2011 se programu zúčastnilo celkem 7 tříd, dohromady 127 dětí. Data se ale podařilo získat pouze od čtyř tříd. Celkově se podařilo získat data od 53 dětí, z toho 26 dívek a 27 chlapců. Průměrný věk byl 10,7 roku $(S D=1,15)$. Kontrolní skupinu se nepodařilo vytvořit.

O administraci pretestů byli požádáni učitelé spolupracující se SEV Jizerka. Každý učitel dostal připravené testy a podrobné pokyny pro jejich administraci. Testy byly zadávány před zahájením práce na školní části programu. Protože každá škola mohla postupovat vlastním tempem, mohla se doba od zadání pretestů do zahájení pobytové části programu lišit. Předpokládaná doba byla zhruba jeden měsíc. Zadání posttestu proběhlo poslední den pobytové části programu jako poslední aktivita. Zadání vždy provedl pracovník SEV Jizerka podle pokynů pro administraci.

Následně byla data zpracována externím evaluátorem. Byly vyřazeny dotazníky, které nebylo možno spárovat podle identifikačního klíče. Protože výsledná množina byla poměrně malá, nevycházela analýza z porovnávání průměrných hodnot odpovědí na jednotlivé položky, ale ze součtů bodů získaných za jednotlivé primární a sekundární faktory.

Protože šlo o první použití nástroje $v$ českém prostředí, bylo nutno vyhodnotit reliabilitu jednotlivých částí nástroje. Analýza vedla k několika změnám. Sekundární faktory Ochrana a Využívání měly poměrně uspokojivou interní reliabilitu (test Cronbachova alfa). Ze škály Ochrana musely být nicméně vyřazeny tři položky a ze škály Využívání jedna položka. Všechny tři vyřazené položky ze škály Ochrana tvořily primární dimenzi Péče o zdroje. Není jasné, proč právě tento faktor nesouvisel s ostatními. V upravené podobě se tedy Ochrana skládá pouze z Odhodlání k podpoře a Radosti z prírody.

Výsledné hodnoty Cronbachova testu byly po úpravě alfa=0,81 při $\mathrm{N}=53$ respondentů pro Ochranu a alfa $=0,61$ pro Využívání. Přestože hodnota Cronbachova alfa pro Využívání není př́liš vysoká, je možné ji považovat za akceptovatelnou (Chráska, 2007; Mertens, 2010).

Větší problémy přinesla analýza škály NEP, jehož reliabilita byla př́liš nízká. Po zvážení bylo proto rozhodnuto tuto část testu nevyužít.

Problematická byla $v$ některých př́padech i reliabilita jednotlivých primárních faktorů. Dobrou reliabilitu měly faktory Odhodlání k podpoře (alfa $=0,79)$ a Radost z přírody (alfa $=0,6)$. Reliabilita Péče o zdroje byla př́liš nízká a vzhledem $\mathrm{k}$ tomu, že faktor nebyl konzistentní s ostatními v rámci sekundárního faktoru Ochrana, byla tato část $z$ testu vyřazena. Faktory Měnění prírody a Dominance měly reliabilitu pod doporučovanou hladinou $(>0,7)$. Protože ale nadřazený sekundární faktor Využívání přírody měl po vypuštění jedné položky uspokojivou reliabilitu, byla tato část v analýze zachována. 
Po celkovém zvážení reliability nástroje bylo rozhodnuto provést analýzu pouze na úrovni sekundárních faktorů, tj. Ochrana a Využívání.

Pro každý ze sekundárních faktorů byly sečteny bodové zisky. Porovnání statistických rozdílů mezi pretestem a posttestem bylo provedeno pomocí párového Wilcoxonova testu, statistická významnost vždy $a=0,05$.

\section{Zjištění}

Výzkum neprokázal, že by program ovlivňoval některý z obou sledovaných faktorů. Přestože u faktoru Ochrana došlo k mírnému posílení souhlasu s postoji podporujícími ochranu přírody, naměřený rozdíl není statisticky významný:

Tab. č. 1 Porovnání rozdílů hodnot faktoru Ochrana před programem a po něm.

\begin{tabular}{|l|l|l|l|l|l|l|l|}
\hline & N platných & Průměr & Medián & Modus & $\begin{array}{l}\text { Četnost } \\
\text { modu }\end{array}$ & Z & p \\
\hline Součet před & 53 & 24,52 & 26 & 27 & 8 & 1,08 & 0,27 \\
\hline Součet po & 53 & 25,2 & 26 & 30 & 8 & & \\
\hline
\end{tabular}

Pozn.: "Z" udává hodnotu Wilcoxonova testu, „p" udává pravděpodobnost náhodného vzniku rozdílu.

Stejné výsledky přinesla i analýza faktoru Využívání. Mírné snížení souhlasu s postoji vyjadřujícími souhlas s využíváním přírody pro uspokojování lidských potřeb opět není statisticky významné:

Tab. č. 2 Porovnání rozdílů hodnot faktoru Využívání před programem a po něm.

\begin{tabular}{|l|l|l|l|l|l|l|l|}
\hline & N platných & Průměr & Medián & Modus & $\begin{array}{l}\text { Četnost } \\
\text { modu }\end{array}$ & $\mathbf{Z}$ & p \\
\hline Součet před & 53 & 17,18 & 18 & 22 & 9 & 0,84 & 0,4 \\
\hline Součet po & 53 & 16,77 & 17 & 16 & 8 & & \\
\hline
\end{tabular}

Pozn.: "Z" udává hodnotu Wilcoxonova testu, „p" udává pravděpodobnost náhodného vzniku rozdílu.

\section{Diskuse}

Evaluace neprokázala, že by program ovlivňoval sledované postoje k životnímu prostředí. Toto zjištění je třeba interpretovat nejprve z pohledu limitů výzkumu. Protože vzorek byl poměrně malý, je možné, že případný menší efekt programu na sledované faktory nebyl naměřen (chyba druhého typu). Je možné, že při větším počtu respondentů by takový efekt byl zaznamenán. 
Evaluaci je dále třeba interpretovat $v$ kontextu předchozích zjištění. Je možné předpokládat, že program poměrně účinně rozvíjí znalosti dětí v oblasti vybraných environmentálních konceptů, rozšiřuje jejich znalost Jizerských hor a může mít také dílčí vliv na dovednosti související se zpracováváním informací o životním prostredí (tento aspekt by ale měl být ještě dále ověřován). Postoje k využívání, respektive ochraně prírody představují obecnější rovinu možných efektů programu, které nejsou součástí jeho explicitně uvedených cílů. Na druhé straně je možné se zamyslet nad tím, proč by program mohl takové postoje rozvíjet, a v návaznosti, jaké změny by v něm mohly být provedeny, pokud by se takový záměr stal součástí jeho cílů.

Je zjevné, že program se dotýká každého z pěti primárních faktorů, které byly součástí analýzy. Bylo by možné předpokládat, že konfrontace dětí s environmentálním problémem, který vznikl v důsledku lidské činnosti, posílí jejich odhodlání chránit přírodu a zproblematizuje tezi o lidské nadřazenosti a právu měnit př́rodu podle svých představ. Žáci $v$ rámci pobytové části tráví většinu času aktivitami, při kterých jsou $v$ př́mé interakci $\mathrm{s}$ přírodou. To by mohlo posílit jejich radost $z$ pobytu $v$ prírodě. Přestože test byl přeložen ze standardizovaného vzoru, některé položky prímo odkazují na témata Vyšetřování (spotřeba energie, ochrana mokřadů).

Pokud ale taková vazba existuje, je zjevně přiliš slabá na to, aby se projevila v testu. To koresponduje s předchozími zjištěními (Vlachová \& Činčera, 2011), podle kterých sice žáci v průběhu programu zpracovávají informace, ale nejsou schopni je využít k tvorbě vlastního názoru.

Příčinou tohoto deficitu může být i to, že program k zaujímání postojů žáky explicitně nevede. Pokud by program usiloval o výraznější ovlivňování postojů, měl by se o to pravděpodobně snažit zařazením cílených aktivit, které by žáky vedly k explicitnímu vyjádření svých postojů na daná témata. Podle Ajzena (1991) má na vytváření postojů vliv přesvědčení jedince o důsledcích určitého chování a o postojích jeho referenčních osob (které jsou mu v určitém smyslu vzorem). V návaznosti pak Bamberg a Mösser (2007) předpokládají, že na vytvoření určité morální normy a souvisejícího environmentálního postoje, se podílí přesvědčení o vlastní provázanosti s problémem (interní atribuce), pocit viny a vědomí související sociální normy. Dủležitou úlohu pro vytváření proenvironmentálních hodnot dále hraje přímá zkušenost z pobytu $v$ přírodě; záleží ovšem také na povaze a interpretaci tohoto pobytu. Podle Bögeholzové (2006) mají na formování proenvironmentálních postojů a chování vliv především estetické, vědecké a ekologické typy zážitků v přírodě, méně již zážitky instrumentální či sociální.

V praxi environmentální výchovy Ize najít př́klady strategií, které s těmito principy úspěšně pracují. Emmonsová (1997) popisuje tři hlavní druhy prostředků, které vedly žáky ke změně postojů $\mathrm{k}$ ochraně pralesa $v$ Belize. Těmi bylo modelové chování lektora, prostor pro výměnu názorů na dané téma a zprostředkování přímé zkušenosti. Původní negativní postoj dětí $\mathrm{k}$ hadům se tak lektorům podařilo měnit pomocí projevovaného zájmu o hady (model), diskuse o hadech (vytváření sociální normy) a vlastního pozorování (přímá zkušenost).

Modelové chování lektora a přimá zkušenost jsou strategie uplatňované i v programech Sunship Earth (Matre, 1979) a Earthkeepers (Matre \& Johnson, 1998). Oba programy se snaží formovat obecné proenvironmentální postoje reprezentované $v$ TEQ zájmem o ochranu přírody a nezájmem o její využívání pro lidské účely (Ochrana + Využívání -). Oba programy používají širokou škálu prostředků pro zprostředkování přímé zkušenosti dětí s přírodou, at' již to jsou známé procházky po Zemi (Matre \& Hoessle, 1980) či jiné typy "ponořujících aktivit” (Matre, 1999). Pozitivní postoje jsou v programech důsledně modelovány lektorem. Sociální normy jsou dále upevňovány řadou "posilujících" prostředků, pomocí kterých jsou žáci odměňováni za svoji všímavost a ochotu "ponořit se" do okolní prírody.

Ve Vyšetřování je přímá zkušenost z pobytu v přírodě zastoupena terénním výzkumem a interpretativními výlety do prírody. To by odpovídalo vědeckému 
a ekologickému typu prožitku (Bögeholz, 2006). Pravděpodobně jsou ale málo zastoupeny aktivity umožňující estetický typ prožitku, jež jsou založeny na smyslovém vnímání a oceňování krásy prírody. $V$ programu by proto mohla být tato dimenze podpořena zařazením některých z "ponořujících" aktivit z programů výchovy o Zemi. Důležitým faktorem je také čas. Je pravděpodobné, že pětidenní varianta programu umožní tento typ aktivit zařazovat ve větším rozsahu než třídenní. Protože všechny školy ve zkoumaném vzorku absolvovaly pouze tř́denní variantu, je možné, že na posílení radosti z pobytu $\checkmark$ prírodě nebylo dost času.

Ve Vyšetřování je poměrně silně zastoupena informační složka, která má pomoci žákům vyhodnotit vliv jednotlivých "stop". Je možné, že by dopad programu na formování postojů posílilo, pokud by namísto části informačních bloků žáci získali čas k formulaci a obhajobě vlastních postojů. Program vede žáky po linii "seznam se s problémem prozkoumej př́činy - prezentuj výsledky". Chybí ale aktivity, ve kterých by žáci formulovali své postoje například $\mathrm{k}$ tomu, zda určitý typ zásahu do lesů $v$ Jizerských horách byl či nebyl ospravedlnitelný, a na obecnější rovině, jaké formy zásahu člověka do prírodního prostředí jsou přijatelné a jaké nikoliv. Aktivity tohoto druhu by mohly být zařazeny po vhodném rozšíření programu po ukončení jeho pobytové části.

Prostředkem $\mathrm{k}$ otevření diskuse o obecnějších postojích žáků k ochraně a využívání př́rody by mohly být také tematické interpretativní výlety. $V$ současné podobě programu jsou žáci vedeni po několika okružních cestách, kde se formou výkladu seznamuji s různými formami zásahů člověka do př́rodního prostředí. Efektivitu tohoto prostředku by mohlo zvýšit, pokud by výlety byly zpracovány podle zásad tematické interpretace. Ty předpokládají, že průvodce postaví trasu jako ilustraci určité teze, která je na jednotlivých stanovištích z různých úhlů názorně prezentována. Trasa tak tvoří jeden vnitřně provázaný celek (Ham, 1992). Pokud by tématem takové cesty bylo například Měnění přírody a tezí např.: „Pokud člověk neuváženě mění okolní přírodu, často to má nedozírné následky” , žáci by přirozeně zahájili diskusi, ve které by formovali související postoje k využivání prírody.

Je otázkou, jak rozsáhlé ambice má mít program, který je primárně zaměřen na posilování vztahu k místu, znalost ekologických pojmů a analýzu jednoho environmentálního problému. Je možné, že snahou ovlivňovat prostřednictvím analýzy konkrétního problému obecnější postoje by se realizátoři dostali na křehký led přemrštěných ambicí a rizika manipulace $s$ postoji dětí. Je ale také možné, že $v$ současné podobě program stále ještě nenaplnil svưj potenciál a že pomocí drobných úprav a s citlivým respektem $\mathrm{k}$ názorům dětí je možné dosáhnout efektu přesahujícího hranice dílčí a regionální problematiky. To je ostatně otázka, kterou je možné klást nejenom na SEV Jizerka.

Výzkum také ukázal, že i standardizované nástroje pro sběr dat je třeba používat uvážlivě. $V$ TEQ bylo zapotřebí provést změny, zahrnující odstranění celého jednoho faktoru z další analýzy. Kvůli nízké reliabilitě nebylo také možné využít doplňující devítipoložkovou škálu NEP. Pro další šetření je zapotřebí zvážit použití TEQ v upravené verzi (v. príloha 2), př́padně pokusit se nástroj ještě více vyladit. Pokud by pro stejnou věkovou skupinu bylo třeba použít NEP, bylo by pravděpodobně vhodnější použít jinou verzi, př́ípadně nástroj dále upravovat.

Na místě je také diskuse o validitě nástroje pro měření environmentálních postojů dětí v České republice. Je možné, že přes rozsáhlé ověřování na vzorku dětí ve Spojených státech (Johnson \& Manoli, 2011) není nástroj pro domácí použití vhodný. Vzhledem k malému počtu respondentů je ale třeba hodnocení interní reliability použitého testu chápat jako orientační a spíše jako vstupní příspěvek do diskuse o validitě nástroje pro jeho použití v domácím kontextu.

Východiskem pro další úpravy může být kritika původní škály ENV/MOV, která je hlavní částí TEQ. Milfont a Duckitt (2004) upozornili na některé problémy, které tento 
nástroj má. Podle jejich analýzy je sice základní dvojdimenzionální struktura (Ochrana a Využívání) nástroje oprávněná, obě dimenze ale obsahují větší počet faktorů, než Bogner a Wiseman (in Johnson \& Manoli, 2008) předpokládali. To otevírá možnost sestavení nového nástroje s vyšší reliabilitou.

Ke zvážení je také využití jiných nástrojů pro měření souvisejících proměnných. Jednou z možností by bylo využití dotazníku Láska k přírodě a zájem o přírodu (LCN) (Perkins, 2010). Nástroj se skládá z pouhých patnácti otázek a je možné, že by pro potřeby evaluace vlivu programu na postoje k př́rodě byl vhodnější než TEQ (Perkins, 2010).

Nelze také vyloučit, že nedostatky nástroje vznikly $v$ důsledku jeho překladu do češtiny, při kterém mohlo dojít k posunu významů. Možnou alternativou je proto také kritická revize českého překladu a jeho další ověřování. Východiskem mưže být modifikovaná podoba nástroje publikovaná po realizaci prezentovaného výzkumu pod označením 2-MEV (Johnson \& Manoli, 2011).

Výzkum vlivu programů environmentální výchovy na proenvironmentální postoje dětí je důležité téma a všechny další výzkumy, které k němu v českém prostředí proběhnou, znamenají důležitý příspěvek k porozumění rozvoji domácího oborového diskursu.

\section{Literatura}

- Ajzen, I. (1991). The Theory of Planned Behavior. Organizational Behavior and Human Decision Process, 50, 179-211.

- Bamberg, S., \& Möser, G. (2007). Twenty years after Hines, Hungerford, and Tomera: A new meta-analysis of psycho-social determinants of pro-environmental behaviour. Journal of Environmental Psychology, 27(1), 14-15. Retrieved from http://linkinghub.elsevier.com/retrieve/pii/S0272494406000909 http://dx.doi.org/10.1016/j.jenvp.2006.12.002

- Bezouška, A., \& Činčera, J. (2007). Vliv environmentální profilace středních škol na proenvironmentální postoje a jednání studentů. Envigogika, 2(3), Retrieved from http://www.envigogika.cuni.cz/index.php/Envigogika/article/view/20 http://dx.doi.org/10.14712/18023061.20

- Schmutzerová, L., \& Bílek, M. (2010). Jak hodnotili čeští patnáctiletí žáci základních škol a studenti víceletých gymnázií environmentální problémy.Envigogika, 5(2), 10-14712. Retrieved from http://www.envigogika.cuni.cz/index.php/Envigogika/article/view/54 http://dx.doi.org/10.14712/18023061.54

- Bögeholz, S. (2006). Nature experience and its importace for environmental knowledge, values and action: recent German empirical contribution. Environmental education research. Environmental education research, 12(1), 65-84. Retrieved from http://www.tandfonline.com/doi/abs/10.1080/13504620500526529 http://dx.doi.org/10.1080/13504620500526529

- Činčera, J., Kavan, D., \& Šeldbauer, J. (2010). Program Vyšetrování jizerskohorské katastrofy pro 4.-6. tř́du ZŠ. [pracovní listy]. Liberec: Společnost pro Jizerské hory.

- Činčera, J., \& Štěpánek, P. (2007). Výzkum ekologické gramotnosti studentů středních odborných škol. Envigogika, 2(1), 10-14712. Retrieved from http://www.envigogika.cuni.cz/index.php/Envigogika/article/view/12 http://dx.doi.org/10.14712/18023061.12

- Dunlap, R. E., \& Van_Liere, K. D. (1978). The new environmental paradigm: a proposed measuring instrument and preliminary results. The Journal of Environmental Education, 9(9), 10-19. 
http://www.tandfonline.com/doi/abs/10.1080/00958964.1978.10801875 http://dx.doi.org/10.1080/00958964.1978.10801875

- Dunlap, R. E., van Liere, K. D., Mertig, A. G., \& Jones, R. E. (2000). Measuring Endorsement of the New Ecological Paradigm: A Revised NEP Scale - Statistical Data Included. Journal of Social Issues, 56(3), 22-4537. Retrieved from http://doi.wiley.com/10.1111/00224537.00176 http://dx.doi.org/10.1111/0022-4537.00176

- Emmons, K. M. (2011). Perceptions of the Environment while Exploring the Outdoors: a case study in Belize. Environmental Education Research, 3(3), 327-344.

- HAM Sam H, (1992). Environmental interpretation : A practical guide for people with big ideas and small budgets. : Colorado : Fulcrum Publishing.

- Hungerford, H. R., \& Volk, T. L. (1990). Changing Learner Behavior Through Environmental Education. The Journal of Environmental Education, 21(3), 8-21. Retrieved from http://www.tandfonline.com/doi/abs/10.1080/00958964.1990.10753743 http://dx.doi.org/10.1080/00958964.1990.10753743

- Miroslav, C. (2007). Metody pedagogického výzkumu. Praha: Portál.

- Johnson, B., \& Manoli, C. C. (2008). Using Bogner and Wiseman's Model of Ecological Values to measure impal on an earth education programme on children's environmental perceptions. Environmental Education Research, 14(2), 115-127. Retrieved from http://www.tandfonline.com/doi/abs/10.1080/13504620801951673 http://dx.doi.org/10.1080/13504620801951673

- Manoli, B., \& Constantinos, C. (2008). Using the Model of Ecological Values to Examine Stability of and Changes in Children's Environmental Perceptions Over Time. Paper presented at the Annual Meeting of the National Association of Research in Science Teaching. Baltimore. .

- Johnson, B., \& Manoli, C. C. (2010). The 2-MEV Scale in the United States: A Measure of Children's Environmental Attitudes Based on the Theory of Ecological Attitude. The Journal of Environmental Education, 42(2), 84-97. Retrieved from http://www.tandfonline.com/doi/abs/10.1080/00958964.2010.503716 http://dx.doi.org/10.1080/00958964.2010.503716

- La Trobe, , H. L, , \& T. G, (2000). A modified NEP/DSP environmental attitudes scale. The Journal of Environmental Education, 32(1), 12-20. Retrieved from http://www.tandfonline.com/doi/abs/10.1080/00958960009598667 http://dx.doi.org/10.1080/00958960009598667

- Manoli, C. C., Johnson, B., \& Dunlap, R. E. (2007). Assessing children's environmental worldviews: Modifying and validating the New Ecological Paradigm Scale for use with children. The Journal of Environmental Education, 38(4), 3-13. Retrieved from http://www.tandfonline.com/doi/abs/10.3200/JOEE.38.4.3-13 http://dx.doi.org/10.3200/JOEE.38.4.3-13

- Matre, v. (Steve), (1979). Sunship Earth. An Earth Education Program Getting to Know Your Place in Space. Martinsville: American Camping Association. .

- Matre, v. (Steve), , \& Johnson, B. (1998). Earthkeepers. Greenville: The Institut for Earth Education.

- $\quad$ Matre, S. v., \& Hoessle, K. (1980). . Greenville: The Institute for Earth Education.

- Matre, S. v. (1999). Earth Education .. a new beginning. Greenville: The Institute for Earth Education. 
- Mertens, D. M. (2010). Research and Evaluation in Education and Psychology. Integrating Diversity With Quantitative, Qualitative, and Mixed Methods. Thousand Oaks: Sage. .

- $\quad$ Milfont, T. L., \& Duckitt, J. (2004). The structure of environmental attitudes: A first - and second- order confirmation factor analysis. Journal of Environmental Psychology, 24(24), 289-303. Retrieved from http://linkinghub.elsevier.com/retrieve/pii/S0272494404000489 http://dx.doi.org/10.1016/i.jenvp.2004.09.001

- Perkins, H. (2010). Measuring love and care for nature. Journal of Environmental Psychology, 30(30), 455-463. Retrieved from http://linkinghub.elsevier.com/retrieve/pii/S0272494410000551 http://dx.doi.org/10.1016/j.jenvp.2010.05.004

- Rossi, P. H., Lipsey, M. W., Freeman, H. E, (2004). Evaluation. A Systemic Approach. Thousand Oaks: Sage.

- Petr, S. (2001). ISSP - životní prostředí. Praha: Sociologický ústav Akademie věd České republiky.

- Stern, P. C., Dietz, T., Troy, A., \& Guagnano, Gregory A., Kalof, Linda, (1999). A ValueBelief-Norm Theory of Support for Social Movements: The Case of Environmentalism. Human Ecology Review, 6(6), 81-97.

- Vlachová, E. (2011). Evaluace pobytových programů environmentální výchovy Společnosti pro Jizerské hory. [Diplomová práce]. Vedoucí práce Jan Činčera. Liberec: Technická univerzita.

- Factor Analysis (v1.0.0) in Free Statistics Software (v1.1.23-r7). Office for Research Development and Education (2010). . Retrieved from http://www.wessa.net/rwasp factor analysis.wasp

\section{Př́lohy}

\section{Př́loha 1 Původní TEQ}

Poznámka: Na konci každé položky je uvedeno, zda patří do škály NEP či ENV.

\begin{tabular}{|l|l|}
\hline 1. & Kdybych měl/-a nějaké peníze navíc, dal/-a bych je na ochranu přírody. (ENV) \\
\hline 2. & $\begin{array}{l}\text { Abych v zimě ušetřil/-a energii, zkontroluji, jestli v mém pokoji není př́liš horko. } \\
\text { (ENV) }\end{array}$ \\
\hline 3. & Líbilo by se mi sedět na kraji rybníka a dívat se na motýly. (ENV) \\
\hline 4. & Lidé mají právo měnit své životní prostředí. (ENV) \\
\hline 5. & Stavět nové silnice je tak důležité, že by se kvůli nim měly kácet stromy. (ENV) \\
\hline 6. & Rostliny a zvírata mají stejné právo žít, jako lidi. (NEP) \\
\hline 7. & Na Zemi už žije př́liš mnoho lidí. (NEP) \\
\hline 8. & Pomáhal bych sehnat peníze na ochranu přírody. (ENV) \\
\hline 9. & Když je dost vidět, vždy vypínám světla. (ENV) \\
\hline
\end{tabular}




\begin{tabular}{|l|l|}
\hline 10. & Rád chodím pryč z města do lesa na výlety. (ENV) \\
\hline 11. & Mám radši udržovaný trávník než místa, kde roste tráva divoce. (ENV) \\
\hline 12. & $\begin{array}{l}\text { Protože komáři žijí v bažinách, měly by se bažiny vysušit a jejich půda využívat pro } \\
\text { zemědělství. (ENV) }\end{array}$ \\
\hline 13. & Lidé musí stále dodržovat zákony přírody. (NEP) \\
\hline 14. & Když lidé zasahují do přírody, mívá to špatné následky. (NEP) \\
\hline 15. & Snažím se říkat ostatním, že příroda je důležitá. (ENV) \\
\hline 16. & $\begin{array}{l}\text { Snažím se šetřit vodou tak, že se sprchuji kratší dobu nebo vypínám kohoutek při } \\
\text { mytí zubù. (ENV) }\end{array}$ \\
\hline 17. & Mám rád klid a ticho přírody. (ENV) \\
\hline 18. & Aby měli lidé dost jídla, příroda se musí přeměnit na pole. (ENV) \\
\hline 19. & Lidé by měli vládnout přírodě. (ENV) \\
\hline 20. & Lidé se chovají k přírodě špatně. (NEP) \\
\hline 21. & Plevel by se měl vyhubit, protože zabírá místo rostlinám, které potřebujeme. (ENV) \\
\hline 22. & Lidé jsou dost moudří na to, aby zabránili zničení Země. (NEP) \\
\hline 23. & $\begin{array}{l}\text { Pokud se v našem chování k životnímu prostředí nic nezmění, přijde velká katastrofa. } \\
\text { (NEP) }\end{array}$ \\
\hline 24. & Příroda je dost silná na to, aby zvládla důsledky moderního životního stylu. (NEP) \\
\hline 25. & $\begin{array}{l}\text { Lidé jednou budou o tom, jak funguje příroda, vědět tolik, že ji dokážou ovládat. } \\
\text { (NEP) }\end{array}$ \\
\hline
\end{tabular}

\section{Příloha č. 2 Upravená verze TEQ podle sekundárních faktorů}

\section{Ochrana}

Odhodlání k podpoře

Kdybych měl/-a nějaké peníze navíc, dal/-a bych je na ochranu př́rody.

Pomáhal bych sehnat peníze na ochranu prírody.

Snažím se říkat ostatním, že příroda je důležitá.

\section{Radost z prírody}

Líbilo by se mi sedět na kraji rybníka a dívat se na motýly.

Rád chodím pryč z města do lesa na výlety.

Mám rád klid a ticho př́rody. 
Využívání

Měnění př́rody

Lidé mají právo měnit životní prostředí.

Mám radši udržovaný trávník než místa, kde roste tráva divoce.

Aby měli lidé dost jídla, príroda se musí přeměnit na pole.

Plevel by se měl vyhubit, protože zabírá místo rostlinám, které potřebujeme.

\section{Dominance}

Protože komáři žijí v bažinách, měly by se bažiny vysušit a jejich půda využívat pro zemědělství.

Lidé by měli vládnout prírodě. 
Časopis Envigogika vydává Centrum pro otázky životního prostředí UK. Vývoj časopisu je podpořen projektem OP VK Mezioborová sít udržitelného rozvoje.

Více najdete na internetových stránkách projektu mosur.czp.cuni.cz
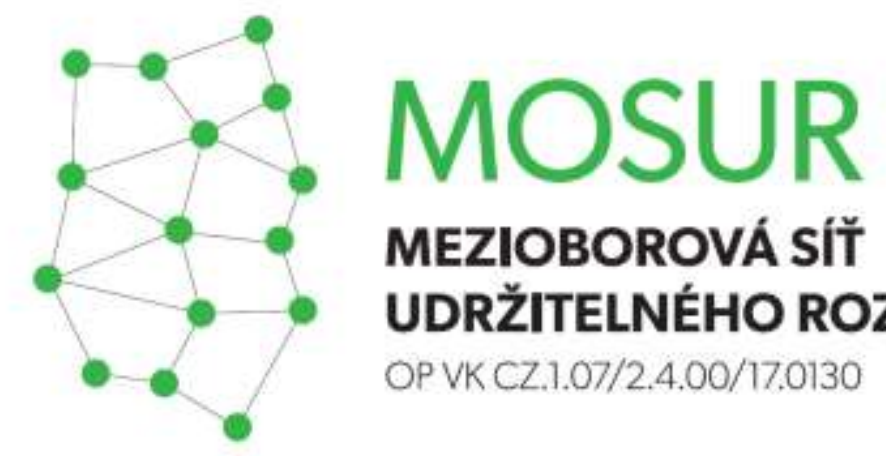

\section{MEZIOBOROVÁ SÍT} UDRŽITELNÉHO ROZVOJE

OP VK CZ.1.07/2.4.00/17.0130
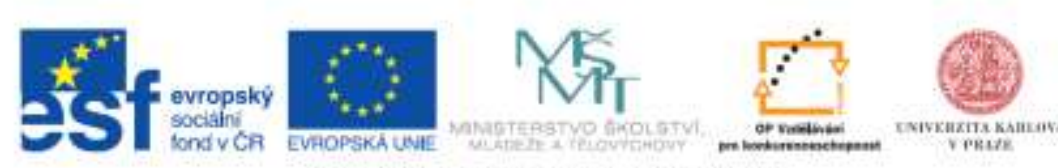

INVESTICE DO ROZVOUE VZDELAVANI 